\title{
The impact of business group affiliation on performance: evidence from China's 'national champions'
}

\begin{abstract}
An important aspect of China's economic reforms has been an ambitious policy to develop a 100 or so large, internationally competitive business groups. Very little is known about these national champion groups or the benefits to subsidiary firms of belonging to them. This study, building from insights and methods used in existing literature, examines the performance of subsidiaries affiliated to China's national champion groups.
\end{abstract}

Key words: China; business groups; national champions; government policy; company performance

JEL Classifications: O1, O2, $\mathrm{P} 3$

02 May 2008 


\section{Introduction}

This paper examines the performance of business group affiliated firms in China and compares their performance with non-affiliated firms. In particular, we examine whether affiliation to a select number of 'national champion' groups is associated with superior performance. By the end of 2006 there were 2,856 officially recognised business groups in China with 27,950 first- tier subsidiaries, employing around 30 million people directly (SSBa, 2007). Beneath this first-tier, moreover, further tiers of firms existed. While the full extent of group membership in China is unknown, case studies suggest it may be very large (Nolan, 2001). As such, the influence and reach of China's business groups is already important. From within these 2,856 groups, moreover, a small subset of around 100 were selected as 'national champion' trial groups. They have received a variety of special policies, directly overseen by China's State Council. These national champion groups are the largest and most institutionally advanced business groups in China (Nolan 2001). Investigating their performance may shed further light on the role of business groups in China's notable economic achievements. Here we examine the performance of listed firms that are affiliated with these trial groups. This, we believe, is a relatively clean test of the benefits of group affiliation in China. Our results shed light on matters of policy relevance, as well as on the broader discussion on whether business groups are to be seen as 'paragons' or 'parasites' in the development process (Khanna and Yafeh, 2007).

In Section 2 we review relevant literature and describe the background to and characteristics of the national champion business groups. Section 3 describes the methodology and data. Section 4 presents our empirical results. Section 5, going beyond our discussion of affiliate performance, raises several further important questions regarding the role of business groups in China today. China's groups are now absorbing more and more firms and incorporating greater volumes of private capital. As such, the sphere of influence of state groups has expanded. The clear boundaries between state and non-state sectors that once existed have become less well defined.

\section{Background and Literature Review}

Khanna and Yafeh (2007) and Morck et al (2005) provide useful reviews of the business group literature which has recently become highly topical. To briefly summarise, a key theme of this literature has been to ask whether business groups may be seen as 'paragons' or 'parasites' (Khanna and Yafeh, 2007). It is argued, for example, that under certain conditions business groups may provide benefits for member firms. Conversely, at other times there may be costs associated with group membership. Among the benefits of group formation, it has been hypothesised that groups may fill institutional voids that are common in emerging markets (and transition economies in particular). By compensating for imperfect or under developed markets in finance, labour, and products, for example, they may help facilitate exchanges that could not happen through the market place. They thus play a positive role in firm development by reducing transactions costs. On the other hand, a number of negative traits may also be associated with business groups, related often to their monopoly powers, engagement in rent-seeking activities and association with crony capitalism, moral hazard and excessive and inefficient investment. One much discussed negative trait is that groups may develop pyramidal structures (La Porta et al, 1999; Morck et al, 2005). Such structures allow an apex firm to control numerous other firms without having made commensurate capital investments. This may lead to corporate governance problems and the 'tunnelling' of resources away from member firms. Here business groups have the potential to destroy value. Such pyramidal groups, moreover, also allow elites, often families or the state, to have enormous economic influence over vast corporate empires (La Porta et al, 1999). More generally, it is speculated this may lead to a range of unhealthy macroeconomic impacts, broadly 
referred to as 'economic entrenchment' (Morck et al 2005, p. 655). In summary, much of the current discussion of business groups is dominated by whether they may be seen as paragons or parasites (Khanna and Yafeh, 2007).

Building from this debate on the various strengths and weaknesses of business groups, a large empirical literature examines whether group affiliated firms perform better than non-group affiliated firms. The evidence, however, is rather mixed. Empirical studies comparing unaffiliated firms to firms that are part of bank-centered keiretsus in Japan, for example, show little evidence of superior performance (Weinstein and Yafeh, 1998). Similarly, Khanna and Palepu (2000a) find that business group affiliation in India is negatively correlated with profitability. In contrast, however, Chang and Choi (1988) find that profits for group-affiliated Korean firms are higher than those of independent firms. Khanna and Palepu (2000b) find that group membership in Chile has a positive impact on both profitability and Tobin's Q. While there is, therefore, some debate as to the exact impact of business groups, Khanna and Yafeh (2007) in their comprehensive review of the business group literature note that the performance of such groups may well be related to the particular institutional environment in which they evolve. Under certain conditions, in other words, business groups may play a positive role.

While interest abounds in business groups, to date only a relatively small literature exists on China's business groups. Smyth (2000), for example, asks 'should China be promoting business groups'? This investigation, while providing valuable observations and analysis, does not undertake any new empirical analysis on business groups per se. Instead it is based largely around a prior literature on large and medium enterprises. Nolan and Wang (1999) and Nolan (2001), based primarily upon case studies, investigate the nature of institutional change within China's large business groups in the context of transition and globalisation. Several further papers employ a quantitative approach to examine whether and under what conditions affiliated members benefit from group membership in China. Keister $(1998,2000)$ examines the performance of 40 of China's largest groups between 1988 and 1990 using a panel data set. She finds that internal finance companies (facilitating internal financial markets) and interlocking directorates (which promote information exchange between group members) are associated with improved performance. She therefore examines the extent to which the internal features of these groups (finance companies, for example) enhance their efficiency. Yiu et al. (2005) examine the profitability of 224 business groups (including all subsidiaries) with another purpose in mind. They wish to find out how groups acquire resources and capabilities so that they can become successful agents to promote economic transformation and growth. They find that group profitability is negatively related to what they call 'endowed resources' (including such things as the age of the group, the extent of government ownership and the prevalence of management with government links) but positively related to what they call 'acquired resources'. Such resources they argue are acquired through actions such as acquisitions, internal capability development and international diversification (Yiu et al 2005). Ma et al (2006), on the other hand, look to examine how business groups fill 'ownership voids' by serving as the direct owners of state owned enterprises in the absence of other private actors. They find that the combination of business group affiliation and state ownership has a positive effect on subsidiary performance. As well, therefore, as substituting for imperfect markets, they argue they may also play an important role in ownership reforms, a point to which we later return.

Finally, the World Bank (2005) has warned of the dangers of forming business groups with state owned parent companies. They argue such parent companies might use the proceeds from the listing of firms, as well from ongoing earnings to fund intra-group structural reform or ill-advised investments (such as speculation in commercial real estate). As such they argue, albeit on the basis of limited empirical data, that such state owned groups may be especially prone to the aforementioned tunnelling problem and require reform. We look to also shed further light on this question. 
Although Keister $(1998,2000)$ and Yiu et al. (2005) show that certain group characteristics have positive impacts on performance, they do not directly examine whether group affiliated firms perform better than other firms, whereas this is the key objective of our paper. To date, moreover, no studies have specifically identified the trial national team groups. We believe, however that these groups provide a particularly good opportunity to investigate the impact of business group affiliation, for reasons we now discuss.

\section{2.l China's national champions}

China's trial groups are much larger and more sophisticated than other groups. In fact, trials and experimentation to develop internationally competitive large business groups can be traced to a policy directive issued by the State Council in December 1991, endorsing 55 business groups to undergo influential trial reforms. In April 1997, a second policy directive selected a further 63 groups to join the trials (Sutherland 2001). Since this time the number of trial groups has remained roughly at 100 with some fluctuation as groups have merged, entered or left. To a great extent the development of the trial groups has adopted the traditional Chinese reform method of using incremental steps, and has followed an iterative and bottom up process of experimentation and feedback (Nolan 2001). The precise objectives of the policies, moreover, have evolved over time. Among the most important and consistently stated objectives of the national champion policy, however, has been to promote institutional change with a view to creating internationally competitive groups that can lead China's integration in the world economy (Nolan 2001; Sutherland 2001).

To achieve this objective a variety of policies were introduced to the national champion groups, including: the development of internal group finance companies; stock market listings; earlier and greater freedoms within the groups giving them greater autonomy in basic decision making; granting of import and export rights; empowerment of the group's core with special rights to incorporate state assets into the group; and the creation of research and technology centres. Table 1 shows the proportion of national champion business groups and other business groups that have adopted these policies. While a proportion of non-champion groups employ all types of policies, national champions employ a higher proportion across the board. For example, $40 \%$ of the national champion groups had finance companies, compared to only $11 \%$ for other groups; $84 \%$ had research and technology centres compared with 55\% for other non-trial groups. Both Nolan (2001) and Keister (1998) make the point that these groups are among the most advanced business groups in China. As such they are arguably in the best possible position to substitute for the imperfect markets that business groups supposedly replace.

\section{INSERT TABLE 1 HERE}

The national champions, moreover, are very large both in absolute size and relative to other groups. When including the parent company (in China referred to as mother company, ' $m u$ gongsi', or 'group company') and subsidiaries with an ownership stake in excess of 50\%, the total aggregate assets, for example, summed to US\$715bn in 2003, representing an average of US\$6.3bn per group. In contrast, the 2,579 other enterprise groups were much smaller in average size (US\$517m) 
(Table 2). Similar differences exist in terms of turnover and number of employees. Remarkably, both national champions and other groups experienced high annual growth, at or above $18 \%$ each year in assets and sales, around twice the speed of national output growth. Employee growth is lower but clearly contrary to the general trend of downsizing within state industry (falling from 55 million in 1992 to 29 million in 2002, for example, in the manufacturing sector (SSB, 2005, p.126)). The trial groups employed around 80,000 per group, compared to 6,000 for non trial groups. Percentage growth rates in assets, turnover and employees are lower for national champions than for other groups, although the absolute growth is much higher. ${ }^{1}$ Between 1997 and $2003, R \& D$ expenditure within the national team increased at an average $30 \%$ growth rate compared to $21 \%$ for other groups, whilst $\mathrm{R} \& \mathrm{D}$ /turnover increased from $9.9 \%$ to $14 \%$ compared to a decrease from $13.4 \%$ to $10.9 \%$ for other groups. The exports of the trial groups increased from US\$9 bn to US\$23.9bn between 1997-2003 (an average increase of 19.5\%). This is similar to the increase observed for other groups. The exports of the national champion groups and the other enterprise groups accounted for $21 \%$ of the total value of all China's exports in 2003, an increase from 17\% in 1997 (SSB 2004b).

\section{INSERT TABLE 2 HERE}

Finally, the number and type of firms participating within China's business groups has also grown. Official data on Chinese business groups records a variety of data on the mother company and the first tier of subsidiaries. The total number of first tier subsidiaries increased from 24,523 to 27,950 between 2002 and 2006. Their share of the total assets of the business groups also increased from $56 \%$ to $66 \%$ (SSB, 2003; SSB, 2007). Among these subsidiaries, moreover, firms registered as state owned became less important as a corporatisation process ensued. An increase in the number and share of limited liability companies (increasing from $9 \%$ to $15 \%$ in terms of asset share) and larger stock limited companies, those potentially listed on China's stock exchanges, took place (increasing from $10 \%$ to $20 \%$ in terms of asset share) (SSB, 2003a; SSBa, 2007). As such the nature and ownership structure of China's business groups, at least at the level of the first tier, appeared to be becoming more diversified. Within the mother company, furthermore, those in which the controlling shareholder was registered as state or collective entity decreased from $100 \%$ to around $47 \%$ between 1997 and 2006, while the number of privately controlled groups increased to $38 \%$ (SSB, 2007a, p. 17). For national champion trial groups, however, nearly all remained state controlled, with the exception of two private and two collective groups.

\subsection{Research questions}

The trial national champion business groups are the largest and most advanced groups in China, benefiting from a raft of experimental changes. Their characteristic features, moreover, have been shown in other contexts to benefit group members. Keister $(1998,2000)$, for example, shows that the presence of group finance companies benefits subsidiaries. If group membership in China is beneficial therefore, arguably the firms most likely to benefit are the subsidiaries of national champions. On the other hand, however, the greater degree of state ownership within the mother

\footnotetext{
${ }^{1}$ For example, the average asset size for the national champions in 1997 is US $\$ 2.3 \mathrm{bn}$ compared to US\$6.3bn in 2003, whilst other enterprise groups increase from an average size of US\$145m in 1997 to US\$517m in 2003.
} 
company, some argue, may encourage the tunnelling of assets away from subsidiary firms (World Bank, 2005). Given these two apparent contradictory forces, as well as the declared policy to create internationally competitive groups, it is of particular interest to further investigate the performance of the national champion subsidiaries involved in the trials to create business groups.

In the next section we describe the methodology and data we employ to examine how these subsidiaries perform relative to other firms.

\section{Methodology and Data}

The methodological approach we employ to test whether affiliation to national champion business groups is beneficial is to examine how listed subsidiaries of national champion business groups perform compared to other listed firms. The examination of group affiliated listed subsidiaries is the approach used by the majority of empirical studies (see e.g., Hoshi et al., 1991; Choi and Cowing, 1999). We focus on listed firms (rather than private firms) because of the more reliable accounting data and additional share price measures available. If group affiliation improves performance, we expect national champion listed affiliates to outperform all other listed firms including both listed subsidiaries of other business (non-national champion) groups and independent listed firms. Again, previous studies have also employed this approach, focusing on whether listed firms are members or not of only the largest business groups (Choi and Cowing, 1999). Unfortunately, it is not possible to compare the performance of member firms before and after their affiliation to national champion groups because it is hard to estimate precisely when particular groups became national champions, ${ }^{2}$ and because listing of group subsidiaries often followed selection of the parent group as a national champion. Our approach therefore, along with prior studies, is prone to selection bias and a potential endogeneity problem (Khanna, 2000).

In order to identify listed subsidiaries of national champion groups we use the Osiris database to examine whether the largest shareholder in all Chinese listed companies (as of year end 2004) is a national champion parent group. If it is, then we use the Osiris company history to establish whether the listed subsidiaries have been subsidiaries of the national team member groups since their initial listing. If so, they are included in the analysis. Of the 1,503 listed Chinese firms on Osiris, we identified 87 as being subsidiaries of national champions. We collect financial accounting data from Osiris and stock market data from Datastream, both of which date from 19982004. In order to be included in the analysis, companies must be listed on both databases and have the financial variables required for the analysis (described below). This results in a final sample of 69 national champion subsidiary listed firms and 983 other listed Chinese firms. The annual data availability for these two sets of firms is reported in Table 3 below.

\section{INSERT TABLE 3 HERE}

\subsection{Performance measures and specification}

We examine the impact of national champion affiliation on three different performance variables; profitability, Tobin's Q, and share return. Profitability is the ratio of profit before interest and taxation divided by net assets. Tobin's Q is book value of total assets plus market value of equity minus book value of equity divided by book value of total assets. Share return is the

\footnotetext{
${ }^{2}$ This is because of the at times informal and experimental nature of the national champion policy. For example, experiments with three large auto makers started in 1986 but the formal announcement of the first batch of trial groups did not take place until 1991.
} 
logarithmic annual share return between $1^{\text {st }}$ January and $31^{\text {st }}$ December, and takes account of both dividends and stock splits (Datastream variable RI). Previous studies have tended to use either one or more of these three measures of performance. We employ all three to ensure that our results are robust to different firm performance measures. The specific econometric regression that we run is as follows:

$$
\begin{gathered}
\text { Performance indicator }=\alpha+\beta_{1} \text { National champion }+\beta_{2} \text { Size }+\beta_{3} \text { Age }+\beta_{4} \text { Growth }+ \\
\beta_{5} \text { Debt }+ \text { Industry dummies }+ \text { Year dummies }+\varepsilon
\end{gathered}
$$

National champion is a dummy variable which is set equal to one for firms that are national team subsidiaries and zero for firms which are not. The coefficient for this dummy variable measures the difference in the performance measure between the 69 national champion subsidiary firms and the other 983 firms. Size is the logarithm of the book value of total assets at the beginning of the year, which is adjusted for inflation by converting into 2004 real terms using the Chinese Consumer Price Index (OECD Factbook 2006). Age is the logarithm of the number of years since the firm was first listed on Datastream. Growth is the annual percentage growth rate in real sales. Debt is long term debt divided by the sum of shareholder funds and long term debt. Industry dummies are industry dummy variables which are set equal to one for each US SIC two digit code, whilst Year dummies are year dummy variables. These independent variables are designed to control for factors that may both determine our dependent variables and differ between group affiliated firms and other listed firms. ${ }^{3}$ We employ ordinary least squares (OLS) regressions and Huber-White (1980) robust standard errors. All variables are winsorized at the $1^{\text {st }}$ and $99^{\text {th }}$ percentiles to remove influential outliers. Table 4 below reports descriptive statistics for the sample.

\section{INSERT TABLE 4 HERE}

\section{Results}

The results of the regression models are reported in Table 5 below. The coefficient for the national champion dummy variable is positive and statistically significant (at the five percent level or higher) in each of the three regressions. This evidence suggests that listed subsidiaries of national champion groups have significantly higher profitability, Tobin's Q, and share returns than other listed firms, after controlling for size, age, growth, leverage, industry and year fixed effects.

The results suggest that these differences are economically as well as statistically significant. In the profitability regression (column 1), the coefficient for the national champion dummy variable is 0.012 , suggesting that national champion subsidiaries exhibit a profit rate some 0.012 higher than other firms. Given that the average profit rate for the overall sample is 0.0599 (see Table 4), the profit rate for national champion subsidiaries is some $20 \%$ higher. Similarly, for the Tobin's Q regression, the national champion coefficient is 0.156 , which compared to an average sample Tobin's Q of 1.9525, suggests that national champion subsidiaries exhibit a Tobin's Q which is $8 \%$ higher than other firms. Finally, for the share return regression, the national champion coefficient is 0.038 compared to an average sample share return of -0.0689 , which is again an economically meaningful difference.

\section{INSERT TABLE 5 HERE}

\footnotetext{
${ }^{3}$ In untabulated univariate tests we find that, compared to other listed firms, national champion listed subsidiaries are significantly larger, but have similar age, growth, and debt.
} 
Our key result from this section is that listed subsidiaries of national champion groups have significantly higher performance than other listed firms. We now subject this finding to a number of robustness tests.

\subsection{Tests of robustness}

Firstly, we test the robustness of our results to alternative definitions of the performance measures used for our dependent variables. Instead of profitability before interest and taxation over net assets, we employ net income divided by shareholders funds. Instead of Tobin's Q we employ market value of equity divided by shareholder funds, and instead of using the logarithm annual share return we use the arithmetic annual return. None of these alternative definitions makes a difference to the results in Table 5. The coefficient for the national champion dummy is significantly positive in each case.

Secondly, we test the robustness of our findings to the inclusion of additional control variables. Our sample of 1,052 firms have their main listing on different stock markets (604 in Shanghai, 423 in Shenzhen, 23 in Hong Kong, and 2 in Singapore). We control for these differences by including dummy variables for the different stock markets. We control for the level of firm diversification by including a dummy variable set equal to one if the primary and secondary 2-digit SIC codes are different from one another. We include a number of additional financial variables as explanatory variables in each regression (intangible assets divided by total assets, current ratio, dividend payout ratio, profitability variance). In all cases, the positive impact of national champion affiliation remains significantly positive. The positive impact of national champion affiliation on profitability and share return is not sensitive to exclusion of any or all of the independent variables in Table 5, although the positive impact on Tobin's Q does not hold if firm size is not controlled for.

A third robustness test concerns the benchmark for our national champion listed firms. In Table 5 we compared them with all other listed firms. We are able to refine this counterfactual to some extent by classifying sample firms according to their largest shareholder. Osiris reports the largest shareholder (for 2004) according to whether it is an industrial firm (841), government agency (93), financial company (80), individual or family (3), or no large shareholder (35). Firstly, we restrict the sample to either national champion subsidiaries or those whose largest shareholder is a government agency (93). Since the latter are state owned but not group affiliated, this allows us to test whether group affiliation has a positive impact on performance for state owned listed firms. The regressions for this subsample show that the coefficient for the national champion coefficient is significantly positive for profitability and share return although insignificantly positive for Tobin's Q. Secondly we compare national champion subsidiaries with those firms whose largest shareholder is an industrial firm (841). This comparison allows us to examine whether affiliation to national champion groups is more beneficial than affiliation to other groups (state owned or nonstate owned groups). ${ }^{4}$ Regressions carried out on this restricted sample show that the coefficient for the national champion dummy variable continues to be significantly positive for the Tobin's $Q$ and share return regressions although insignificantly positive for the profitability regression. Overall, these two tests show that national champion affiliation is beneficial compared to both direct state ownership and to affiliation to other groups (state owned or non-state owned groups).

In summary, the results in this section show that firms that are affiliated with the national champion groups have higher performance. This finding is robust, holding across a range of performance measures, control variables, and benchmark firms. This is consistent with previous

\footnotetext{
${ }^{4}$ We are unable to distinguish between those industrial firms that are state owned and those that are not.
} 
empirical studies on China which show that group affiliation is associated with positive performance impacts (Keister, 1998; Ma et al., 2006).

\section{Summary and Discussion}

We have identified China's most important business groups (the 100 plus 'national champion' trial groups) and investigated the performance of their listed subsidiaries. A sustained government policy over the past 20 years has bestowed upon these groups a wide range of group rights, some of which have been shown to be associated with successful business group performance in other settings. The government's objective is to make these groups internationally competitive. Aggregate data on the groups (including mother and first tier subsidiaries) suggests that, as a whole, these groups are very large and have grown quickly in terms of sales, assets and R\&D expenditures. Going a step further we apply a frequently used approach in the business group literature to examine subsidiary performance (Khanna and Yafeh, 2007). Our analysis of the listed subsidiaries of these national champions shows that they outperform non-affiliates in terms of higher profitability, stock market valuations and share returns.

One interpretation is that institutional changes in the national champion groups are responsible for the observed high performance in member subsidiaries. This argument is consistent with previous studies which find that certain institutional features more prevalent in China's largest groups (such as finance companies and research and development centres) directly improve member performance (Keister, 1998, 2000). Other studies, moreover, concentrating specifically on China's groups, also give reasons as to why groups may provide benefits to member firms. Nolan and Wang (1999), for example, have suggested on the basis of numerous case studies that Chinese groups may pool and distribute heterogeneous resources for member firms (such as management skills, brands, sales and marketing). It has also been suggested that group membership may provide insulation from potential or real political intervention, thus controlling an uncertain political environment while 'improving their access to scarce goods' (Keister, 2000, p. 151). Moving beyond studies of Chinese business groups, studies in other regions of the world also list numerous credible reasons as to why business groups may enhance firm-level performance, a major one being the presence of imperfect markets (Khanna and Yafeh 2007). It is entirely conceivable, of course, that Chinese groups do substitute for missing markets, hence leading to lower transactions costs. Such missing markets are particularly severe in transition economies (Keister, 1998). In other words, in the Chinese context it is possible that business groups are 'paragons' as opposed to parasites. Indeed, the only other study with direct similarities to ours, looking at listed subsidiaries of groups, finds evidence that they may improve subsidiary performance (Ma et al 2006). Smyth (2000), in a synthesis of current arguments, also concludes that groups may be beneficial to firm performance in China. On balance then, there are many reasons and considerable evidence for believing that business groups may improve firm performance in the Chinese context. Indeed, the sheer proliferation of such groups, both state owned and private, would seem to suggest they may enjoy some competitive advantages.

This said, as with other studies in this area, it is important to stress that this interpretation of our results is tentative, because the methodology does not establish causality. The results could instead equally well be explained by national champion groups listing well performing firms, or policy makers successfully 'picking winners'. In addressing whether performance has been better for national champions, moreover, it is impossible to take into account whether there are direct interventions that may lead to better performance among these listed subsidiaries (preferential 
access to material supplies, finance, foreign investment, public procurement and the like) or what the opportunity costs of these interventions are. Clearly, more research is needed to further clarify these issues. Still, it is some interest that the very subsidiaries which have been hypothesised to be most at risk of agency problems and tunneling do not seem to be performing badly, but instead very well. The World Bank (2005), for example, highlighted concerns about the capacity and willingness of state groups to exploit their listed subsidiaries. Clearly, our results suggest this is not the case. Instead, the trend appears more consistent with the goal of creating internationally competitive transnational businesses, one avowed goal of the policy (Nolan 2001).

In highlighting China's business groups as an area of research we believe there are a number of points that warrant mention and further investigation. Firstly, moving beyond the question of the performance of firms affiliated to China's trial business groups, we note that the influence of China's groups now arguably extends the reach of China's state sector beyond the traditional boundaries marked by standard ownership criteria. We have already noted that there were 2,856 officially recognized business groups with over 27,950 first-tier subsidiaries (averaging about 10 per group in which the ownership stake exceeded $50 \%$ ) by the end of 2006. But how large are China's business groups if we include lower tiers of member firms? Delineating the exact boundaries of business groups is notoriously difficult. Different and at times quite vague definitions of what actually constitutes a group, and by extension group membership, exist. Granovetter, in a seminal contribution, notes how groups have an 'invisible nature' (Granovetter 1993, p. 97). Thus practical definitions of business groups are nearly always subjective and vary considerably across countries. In post-war Japan's case, for example, Khanna and Yafeh (2007) define group membership as those firms which send members to the meetings of the 'Presidents Clubs'. The Korea Fair Trade Commission, on the other hand, defines a business group as 'a group of companies of which more than 30 percent of shares are owned by the group's controlling shareholder and its affiliated companies' (the average number of affiliated firms within the chaebols was 27 in 1998) (Bae and Jeong 2007, p.743). Other academics provide rather broad definitions which are quite hard to apply (take Leff's early definition, for example: 'a group of companies that does business in different markets under a common administrative or financial control' and that are 'linked by relations interpersonal trust, on the basis of a similar personal, ethnic or commercial background' (Leff, 1978, p. 663). In short, there is considerable debate on just how business groups should be defined (are social ties, for example, more important than ownership ties?). The official Chinese definition of group membership, however, in including data on first tier subsidiaries, arguably means China's groups appear small in terms of actual membership numbers. If, however, second and lower tier companies are included, China's groups would almost certainly appear considerably larger. The influence of China's business groups, therefore, is almost certainly greater than the already significant scale and reach highlighted by official statistics. Given this, the performance impacts of group affiliation are clearly important to understand.

Secondly, related to this point and also the important issue of affiliate ownership and control, is the question of why business groups, often with controlling shareholders rather than free-standing large enterprises with diffuse ownership, are becoming dominant in the Chinese economy. It is important to note, in this regard, that it has recently been shown that it is only in the UK and US that the free-standing diffuse ownership pattern of corporate governance structure truly exists (La Porta et al, 1999). In this sense the evolution of China's current business group structures, in which some firms may come to control numerous other firms (both publicly listed and non-listed), is not so surprising. In most countries (both developing and developed) large corporations often have 
controlling owners (usually wealthy families) and also pyramidal type control structures using business groups. One feature of these ownership structures is that they may allow the controlling family, or state body in China's case, to vastly expand their control over firms and the economy as a whole 'without undertaking commensurate capital investments' (Morck et al 2005, p. 655). Indeed, one rationale for business groups, considered also to cause agency problems, is that they allow firms to attract large volumes of external capital while maintaining ultimate control over firm members. Raising capital through the creation of business groups has arguably been especially appealing to incumbent state bodies at different levels in China (provincial and city governments, for example). Business groups, therefore, provide attractive possibilities to leverage the influence of state actors, thus facilitating control over large parts of the economy. This phenomenon, whereby elites control vast swathes of an economy through business groups, has been referred to as 'economic entrenchment' (Morck et al 2005). It is also considered to be significant in understanding economic performance across countries.

Thirdly, and following from the points above, as business groups absorb more firms and in turn capital from different sources this leads to the diversification of ownership within business groups. This raises numerous interesting questions about the role such groups play in ownership reform and the boundaries of the traditional state owned economy in China. Much of the discussion, dating from the debate of transition strategies ('gradualism' versus 'big bang' approaches) has dwelt upon the issue of ownership and how this may impact on firm performance. Business groups, however, may play an important role in blurring clear ownership boundaries. This is because they may allow a state-owned parent company, through pyramidal type control chains, to control other non-state firms. Liu and Pei (2005), for example, highlight what they believe to be the prevalence of such control chains and the difficulty this presents in specifying the ultimate owner of listed firms. They note, furthermore, that many firms officially designated as being non-state owned are in many instances actually ultimately controlled by state owned business groups. The true extent of such control chains and the role business groups play in expanding their control over the non-state sector is an important question and warrants greater research. By 2006, for example, only 5,493 of the 27,950 first tier subsidiaries in China's business groups remained registered as state owned. Over 14,000 , by contrast, had been transformed into limited liability and 1,882 into stock holding companies, opening up the way for ownership diversification and, arguably, the extension of the control of elite state groups over non-state subsidiaries.

\section{Conclusion}

The primary purpose of this paper was to investigate the performance of the listed subsidiaries of China's trial business groups. Given the outstanding features of these groups, including their greater institutional development, higher concentration of state ownership among the mother company and their centrality to Chinese industrial policies (to create internationally competitive business groups), it is of particular interest to investigate their performance. Our results are surprising, in so far as a clear tendency to outperform other listed firms was found. We have discussed possible interpretations for this and conclude that it appears consistent with the research to date on China's business groups.

To conclude, it is important to frame our findings within a broader context. The transition orthodoxy, a paradigm strongly influenced by the ideas of mainstream neoclassical economics, called for the rapid privatisation of large state owned enterprises, rapid liberalisation and close integration with international markets. It also emphasised the importance of small private enterprises in promoting economic growth and the impossibility of turning round state owned enterprises (World Bank, 2002). The success of China's economic reforms, therefore, has been 
described by recourse to the analogy of 'a dry prairie, parched by years of planning, awaiting the sprinklings of market reform' (World Bank, 1997). In this analogy, success was attributable solely to the 'shoots' of small private enterprises emerging in response to market forces. In so far as it envisaged large enterprises taking a centre stage in economic development, it did so with reference to the type of structures noted in the advanced capitalist economies, particularly the US and Britain (i.e. free standing firms with diffuse ownership). This might be applicable to US or British firms, which are generally, if not always, freestanding. Recent research, however, shows these types of governance structures are highly atypical (La Porta et al, 1999). It is, in fact, more common, particularly for large listed corporations, to belong to business groups, often in a pyramidal form, with an identifiable controlling owner (as opposed to many small shareholders). Such structures may also, and often do, allow small elites to control vast swathes of the corporate sector. The complex types of ownership and control structures that actually predominate throughout the real world, and the important role of business groups, particularly in developing countries with imperfect markets, was therefore largely overlooked by this orthodox view. Here we have highlighted the importance of these large groups and the need to further deepen our study of them. 


\section{Bibliography}

Bae, K. H., Jeong, S. W. 2007. The Value-relevance of Earnings and Book Value, Ownership Structure, and Business Group Affiliation: Evidence From Korean Business Groups. Journal of Business Finance and Accounting, vol.34, no.5., pp 740-766.

Chang, S.J., and Choi, U. 1988. Strategy, structure and performance of Korean business groups: a transactions cost approach, Journal of Industrial Economics, vol. 37, no. 2., pp 141-158.

Chang, S., and Hong, J. 2000. Economic performance of group affiliated companies in Korea: Intra-group resource sharing and internal business transactions, Academy of Management Journal, vol. 43, pp. 429-448.

Chang, S., and Hong, J. 2002. How much does the business group matter in Korea? Strategic Management Journal, vol. 23, pp. 265-274.

Choi, J.P., and Cowing, T.G. 1999. Firm behavior and group affiliation: the strategic role of corporate grouping for Korean firms, Journal of Asian Economics, vol. 10, pp. 195-209.

Granovetter, M. 1995. Coase Revisited: Business groups in the Modern Economy, Industrial and Corporate Change, vol.4, 1, pp. 93-130.

Hoshi, Takeo, Anil Kashyap, and David Scharfstein, 1991, Corporate structure, liquidity, and investment: Evidence from Japanese industrial groups, Quarterly Journal of Economics 106, 3360.

Keister, L. 1998. Engineering growth: business group structure and firm performance in China's transition economy, American Journal of Sociology, vol. 104, pp. 404-440.

Keister, L. 2000. The Structure and Impact of Interfirm Relations during Economic Development, Oxford University Press, Oxford.

Khanna, T. 2000. Business groups and social welfare in emerging markets: existing evidence and unanswered questions, European Economic Review, vol. 44, pp. 748-761.

Khanna, T., and Palepu, K. 2000a. Is group membership profitable in emerging markets? an analysis of diversified Indian business groups, Journal of Finance, vol. 55, pp. 867-891.

Khanna, T., and Palepu, K. 2000b. The future of business groups in emerging markets: long-run evidence from Chile, Academy of Management Journal, vol. 43, pp. 268-285.

Khanna, T., and Yafeh Y., 2007. Business groups in emerging markets: paragons or parasites? Journal of Economic Literature, vol. XLV, pp.331-372.

La Porta, Rafael, Florencio Lopez-de-Silanes, and Andrei Shleifer. 1999. "Corporate Ownership around the World." Journal of Finance, vol. 54, no. 2, pp. 471-517.

Leff, N. 1978. Industrial organisation and entrepreneurship in the developing countries: the economic groups, Economic Development and Cultural Change, vol. 78. pp. 661-674. 
Liu, G. and Pei, S. 2005. The Class of Shareholdings and its Impacts on Corporate Performance: A case of state shareholding composition in Chinese public corporations, Corporate Governance, vol. 13, no. 1 , pp. 46-59.

Ma, X., Yao, X., and Xi, Y. 2006. Business group affiliation and firm performance in a transition economy: A focus on ownership voids, Asia Pacific Journal of Management, vol. 23, pp. 467-483.

Morck, R., Wolfenzon, D. and Yeung, B. 2005. Corporate Governance, Economic, Entrenchment, and Growth, Journal of Economic Literature, vol. XLIII, pp. 655-720

Nolan, P. 1996. Large firms and industrial reform in former planned economies: the case of China, Cambridge Journal of Economics, vol. 20, no. 6., pp 1-29.

Nolan, P. 2001. China and the Global Business Revolution, Palgrave, Basingstoke.

Nolan P. 2002. China and the global business revolution, Cambridge Journal of Economics, vol. 26, no. 1 .

Nolan, P. and Wang, X. 1999. Beyond privatization: Institutional innovation and growth in China's large state-owned enterprises, World Development, vol. 27, no 1.

OECD, 2006. OECD Factbook 2006. OECD, Paris, France

Smyth, R. 2000. Should China be promoting large-scale enterprises and enterprise groups?, World Development, vol. 28, pp. 721-737.

SSBa. (State Statistical Bureau). 2002 - 2007. Zhongguo Da Qiye Jituan Nianjian(China's Large Business Group Yearbook), Zhongguo Tongji Chubanshe, Beijing. (in Chinese)

SSBb. (State Statistical Bureau). (various years). China Statistical Yearbook, Zhongguo Tongji Chubanshe, Beijing. (in Chinese)

Sutherland, D. 2001. China's Large Enterprises and the Challenge of Late Industrialisation, Routledge, London.

Weinstein, D., and Yafeh, Y. 1998. On the costs of a bank-centered financial system: evidence from the changing main bank relations in Japan, Journal of Finance, vol. 53, pp. 635-672.

World Bank. 1993. The East Asian Miracle: Economic Growth and Public Policy, Oxford University Press, Oxford.

World Bank. 1997. China 2020, The World Bank, Washington, D.C.

World Bank. 2002. Transition The First Ten Years: An Analysis and Lessons for Eastern Europe and the Former Soviet Union, The World Bank, Washington D.C.

Yiu, D, Bruton G.D., and Yuan L. 2005. Understanding business group performance in an emerging economy: acquiring resources and capabilities in order to prosper, Journal of Management Studies, vol. 42, no. 1, pp. 183, 206.

Zhang, L.Y. 2004. The roles of corporatization and stock market listing in reforming China's state industry, World Development, vol. 32, no. 12., pp. 2031-2047.

World Bank, 2005 SOE Dividends: How Much and to Whom? World Bank policy note. World Bank, Beijing Office. 
Table 1. National champion groups and other business groups: Institutional development

\begin{tabular}{lcc}
\hline & $\begin{array}{c}\text { National champion } \\
\text { groups (\%) }\end{array}$ & Other groups (\%) \\
\hline Full investment autonomy & 95 & 91 \\
International financing rights & 46 & 25 \\
Export credit guarantees & 84 & 72 \\
Independent import and export rights & 96 & 69 \\
Combined group tax payment & 61 & 26 \\
Rights to contract international projects & 82 & 53 \\
Rights to approve foreign business affairs & 74 & 9 \\
Technology and research centres & 84 & 55 \\
Finance companies & 40 & 11 \\
\hline
\end{tabular}

Note: This table reports the institutional development of 113 national champion groups and 2579 other business groups in 2006. See Nolan (2001) for further details of these measures.

Source: SSBa (2006, p. 404). 
Table 2. National champion groups and other business groups: Aggregate financial characteristics

\begin{tabular}{lcccccccc}
\hline & 1997 & 1998 & 1999 & 2000 & 2001 & 2002 & 2003 & $\begin{array}{c}\text { Average annual } \\
\text { change (\%) }\end{array}$ \\
\hline Panel A: National champion groups & & & & & & & & \\
Number & 119 & 121 & 126 & 119 & 119 & 116 & 113 & -0.8 \\
Assets (US\$ bn) & 278.2 & 408.1 & 547.4 & 544.0 & 581.0 & 635.4 & 715.3 & 18.2 \\
Turnover (US\$ bn) & 135.1 & 193.8 & 262.7 & 275.6 & 306.3 & 358.2 & 444.3 & 22.7 \\
Employees (number) & 7.6 & 9.9 & 11.2 & 9.9 & 9.3 & 8.8 & 9.0 & 3.8 \\
R\&D (US\$ bn) & 13.4 & 20.1 & 30.2 & 35.4 & 37.8 & 49.4 & 62.0 & 30.1 \\
Exports (US\$ bn) & 9.0 & 9.8 & 16.5 & 17.6 & 17.7 & 21.7 & 23.9 & 19.5 \\
Profits (US\$ bn) & 5.3 & 4.2 & 8.9 & 17.2 & 17.5 & 24.4 & 32.3 & 43.0 \\
R\&D/turnover (\%) & 9.9 & 10.4 & 11.5 & 12.8 & 12.3 & 13.8 & 14.0 & 6.1 \\
Exports/turnover (\%) & 6.7 & 5.1 & 6.3 & 6.4 & 5.8 & 6.1 & 5.4 & -2.4 \\
\hline Panel B: Other groups & & & & & & & & 2.5 \\
Number & 2,250 & 2,351 & 2,631 & 2,536 & 2,591 & 2,511 & 2,579 & 2.4 \\
Assets (US\$ bn) & 328.4 & 399.1 & 504.7 & 745.0 & 961.7 & 1081.9 & 1334.9 & 26.8 \\
Turnover (US\$ bn) & 204.7 & 228.8 & 264.6 & 366.1 & 484.3 & 571.0 & 761.7 & 24.9 \\
Employees (number) & 10.9 & 11.0 & 12.2 & 12.9 & 15.9 & 16.4 & 16.9 & 7.8 \\
R\&D (US\$ bn) & 27.5 & 30.8 & 33.3 & 41.9 & 57.5 & 62.5 & 83.3 & 20.9 \\
Exports (US\$ bn) & 22.1 & 22.6 & 26.7 & 37.6 & 47.4 & 54.0 & 66.9 & 20.9 \\
Profits (US\$ bn) & 9.4 & 8.9 & 11.9 & 17.8 & 21.2 & 25.9 & 34.6 & 25.5 \\
R\&D/turnover (\%) & 13.4 & 13.5 & 12.6 & 11.4 & 11.9 & 10.9 & 10.9 & -3.2 \\
Exports/turnover (\%) & 10.8 & 9.9 & 10.1 & 10.3 & 9.8 & 9.5 & 8.8 & -3.3
\end{tabular}

Note: This table reports the aggregate financial characteristics for national champion groups and other business groups over 1997-2003. We convert the Renminbi values to US dollars assuming 8.3 RMB to 1 US\$. The figures are expressed in 2004 real terms, deflated using the Chinese Consumer Price Index (OECD Factbook 2006). Source: SSBa (2004, pp. 30-3). 
Table 3. Sample description

\begin{tabular}{lccc}
\hline Year & $\begin{array}{c}\text { National champion listed } \\
\text { subsidiaries }\end{array}$ & Other listed firms & Total listed firms \\
\hline 1999 & 37 & 583 & 620 \\
2000 & 39 & 624 & 663 \\
2001 & 53 & 719 & 772 \\
2002 & 56 & 825 & 881 \\
2003 & 62 & 888 & 950 \\
2004 & 66 & 904 & 970 \\
\hline \# firm years & 313 & 4,543 & 4,856 \\
\hline \# unique firms & 69 & 983 & 1,052 \\
\hline
\end{tabular}

Notes: This table reports the firm year observations for the samples used in the analysis on a year by year basis. Column (2) reports the number of firm year observations for all Chinese listed subsidiaries of national champion groups in the Datastream and Osiris databases with all the financial variables described in Table 5 below available. Column (3) reports the number of firm year observations for all other Chinese listed firms in the Datastream and Osiris databases with all the financial variables described in Table 5 below available. Column (4) is the sum of columns (2) and (3). Firms classified as financial or real estate (US SIC 600-699 inclusive) are excluded throughout. 
Table 4. Descriptive statistics

\begin{tabular}{lcccccc}
\hline Variable & \# observations & Mean & Median & $\begin{array}{c}\text { Standard } \\
\text { deviation }\end{array}$ & 25 $5^{\text {th }}$ percentile & $75^{\text {th }}$ percentile \\
\hline Profitability & 4,856 & 0.0599 & 0.0691 & 0.0899 & 0.0267 & 0.1107 \\
Tobin's Q & 4,856 & 2.2870 & 1.9525 & 1.2437 & 1.3699 & 2.9088 \\
Share return & 4,856 & -0.0689 & -0.1440 & 0.3258 & -0.3112 & 0.1477 \\
Size & 4,856 & 11.9820 & 11.9186 & 0.8073 & 11.4163 & 12.4995 \\
Age & 4,856 & 1.4298 & 1.6094 & 0.6451 & 1.0986 & 1.9459 \\
Growth & 4,856 & 0.1882 & 0.1398 & 0.3421 & -0.0201 & 0.3505 \\
Debt & 4,856 & 0.0925 & 0.0365 & 0.1188 & 0.0000 & 0.1524 \\
\hline
\end{tabular}

Notes: This table reports summary statistics on the variables employed in the analysis. Profitability is the ratio of profit before interest and taxation divided by net assets. Tobin's Q is book value of total assets plus market value of equity minus book value of equity divided by book value of total assets. Share return is the logarithm of the annual buy-and-hold share return between $1^{\text {st }}$ January and $31^{\text {st }}$ December, and takes account of both dividends and stock splits Size is the logarithm of the book value of total assets at the beginning of the year, which is adjusted for inflation by converting into 2004 real terms using the Chinese Consumer Price Index (OECD Factbook 2006). Age is the logarithm of the number of years since the firm was first listed on Datastream. Growth is the annual percentage growth rate in real sales. Debt is long term debt divided by the sum of shareholder funds and long term debt. All variables have been winsorized at the $1^{\text {st }}$ and $99^{\text {th }}$ percentiles to remove influential outliers. 
Table 5. Performance of national champion listed subsidiaries

\begin{tabular}{lccc}
\hline Independent & \multicolumn{3}{c}{ Dependent variable } \\
variables & Profitability & Tobin's Q & Share return \\
\hline \multirow{2}{*}{ Intercept } & $-0.184^{* * *}$ & $12.232^{* * *}$ & -0.190 \\
& $-(3.53)$ & $(21.04)$ & $-(1.21)$ \\
National champion & $0.012^{* *}$ & $0.156^{* * *}$ & $0.038^{* *}$ \\
& $(2.38)$ & $(2.95)$ & $(2.47)$ \\
Size & $0.016^{* * *}$ & $-0.773^{* * *}$ & $0.021^{* * *}$ \\
& $(8.86)$ & $-(38.18)$ & $(4.19)$ \\
Age & $-0.014^{* * *}$ & 0.035 & $0.017^{* * *}$ \\
& $-(7.87)$ & $(1.44)$ & $(3.12)$ \\
Growth & $0.091^{* * *}$ & -0.009 & $0.126^{* * *}$ \\
& $(23.72)$ & $-(0.21)$ & $(12.58)$ \\
Debt & $-0.126^{* * *}$ & $-0.234^{* *}$ & 0.048 \\
& $-(11.58)$ & $-(2.19)$ & $(1.61)$ \\
Industry dummies & & & \\
Year dummies & Yes & Yes & Yes \\
& Yes & Yes & \\
\# observations & & & 4,856 \\
$\mathrm{R}^{2}$ & 4,856 & 4,856 & 0.5439 \\
F-statistic & 0.2332 & 0.5146 & $124.06^{* * *}$ \\
\hline
\end{tabular}

Notes: This table reports ordinary least squares regressions of company performance on national champion affiliation and other variables. National champion is a dummy variable set equal to one for all Chinese listed subsidiaries of national champion groups, zero otherwise. Other variables are as defined in Table 5. Industry dummies are dummy variables set equal to one for each US SIC two digit code. All continuous variables have been winsorized at the $1^{\text {st }}$ and $99^{\text {th }}$ percentiles to remove influential outliers. t-statistics are in parentheses and are based on robust standard errors. ${ }^{* * *},{ }^{* *}$ and ${ }^{*}$ denote significance at the $1 \%, 5 \%$, and $10 \%$ level, respectively. 